\title{
David Oliver: What's the verdict on personal health budgets?
}

\section{David Oliver consultant in geriatrics and acute general medicine}

Berkshire

A key component of the NHS long term plan was a set of commitments on personalised care. ${ }^{1}$ These included a target for 200000 people to benefit from personal health budgets by 2023-24. The current number is around $40000 .^{2}$

This raises questions. For instance, will these budgets benefit the right people? Will they introduce risks or bring opportunity costs for other service users? Are they a cost effective use of scarce public resources, or would the money be better spent elsewhere? Are any safeguards required?

In England, personal budgets ${ }^{3}$ and direct payments linked to personalised care plans have existed in social care for some time. Their introduction was partly a response to care that was often depersonalising, paternalistic, and unable to give disabled people the choice and control they wanted. ${ }^{45}$ The Care Act 2014 made personal care budgets mandatory for all eligible recipients. ${ }^{67}$ Unlike the NHS, English social care remains means tested and based on eligibility criteria, not free at the point of care and based on need. ${ }^{8}$ Around a quarter of all social care spending on home based adult care is through direct payments. ${ }^{9}$ There's no shortage of positive personal stories from recipients of personal health or care budgets, or from their parents or carers. ${ }^{10}$ Many say that it's helped transform their lives and care, giving them back more control. ${ }^{11}$ Some healthcare professionals have a very positive view of the potential to revolutionise how they offer treatment, care, and support, helping to make care plans a reality. ${ }^{12}$

NHS England plans to build formal evaluation into its expansion plan for personal health budgets. ${ }^{13}$ But we already have intelligence from earlier multicentre pilots and personal budget evaluations, summarised by the University of Kent's Personal Social Services Research Unit. ${ }^{14}$ And the National Audit Office reported on personal care budgets in 2016. ${ }^{16}$ Its conclusions were mixed, showing that care budgets could improve the holder's experience and save money, but they sometimes increased costs when compared with usual care and were hard for local authorities to administer. It concluded that any benefits were likely to come from improved outcomes for service users and not from any savings.
Critics question whether it's prudent to spend parts of the NHS budget on relatively poorly evidenced models of support when we're systematically failing to provide well proven services. Some fear that the move towards giving money to individuals is ideologically driven and represents further fragmentation and stealth privatisation of public services, using more consumerist approaches. ${ }^{17-19}$

There's also concern that direct payments may leave already vulnerable people with heavy responsibility that may add to their stress, especially without adequate professional support. ${ }^{20}$ And, without sufficient safeguards, people could use their money frivolously or buy substandard care from poorly regulated sources that put them at risk. ${ }^{21}$ Advocates see these issues as a paternalistic failure to cede control. ${ }^{1012}$

Me? I don't think that personal budgets in health and social care, or newer integrated budgets covering both, will be the norm for most service users anytime soon. ${ }^{7}$ I'm less interested in ideology and more concerned about pragmatic, transparent evidence on the value they offer users, coming from scarce public resources-and about the implications and costs for other users needing health and social care.

What do readers think?

\section{Competing interests: See bmj.com/about-bmj/freelance-contributors}

Provenance and peer review: Commissioned; not externally peer reviewed

NHS England. What is personalised care? https://www.england.nhs.uk/personalisedcare/ what-is-personalised-care/.

2 Department of Health and Social Care. Expansion of budgets for personalised health and care support announced. $21 \mathrm{Feb} 2019$. https://www.gov.uk/government/news/expansionof-budgets-for-personalised-health-and-care-support-announced.

3 NHS England. Personal health budgets (PHBs). https://www.england.nhs.uk/personalhealth-budgets/.

4 Age UK. Factsheet 24: Personal budgets and direct payments in social care. Dec 2018. https://www.ageuk.org.uk/globalassets/age-uk/documents/factsheets/fs24_personal budgets_and_direct_payments_in_social_care_fcs.pdf.

5 Disability Rights UK. Personal budgets: the right social care support. 7 Oct 2015. https:/ /www.disabilityrightsuk.org/personal-budgetsthe-right-social-care-support.

6 Parliament UK. Care Act 2014 (s28). http://www.legislation.gov.uk/ukpga/2014/23/section 28/enacted.

7 NHS. Personal budgets and direct payments. 10 Jan 2019. https://www.nhs.uk/conditions/ social-care-and-support-guide/money-work-and-benefits/personal-budgets/. 
8 Curry N. What should a good social care system look like? Nuffield Trust. 4 Apr 2019. https://www.nuffieldtrust.org.uk/news-item/what-should-a-good-social-care-system-looklike\#a-flawed-system.

9 Age UK. Direct payments for social care: options for managing the cash. Jun 2013. https: //www.ageuk.org.uk/Documents/EN-GB/For-professionals/Research/Direct_Payments_ Report_June2013.pdf?dtrk=true.

10 Wigram J. Jenny Wigram: Personal health budgets-the system should be fitted to patients needs. BMJ Opinion 2018 May 18. https://blogs.bmj.com/bmj/2018/05/18/jenny-wigrampersonal-health-budgets-the-system-should-be-fitted-to-patients-needs/.

11 Leonard H. Personal health budgets-a view from the other side. BMJ Opinion 2019 Aug 21. https://blogs.bmj.com/bmj/2019/08/21/helen-leonard-personal-health-budgets-a-viewfrom-the-other-side.

12 Alakeson V. Vidhya Alakeson: What will personal health budgets offer the NHS? BMJ Opinion 2014 Apr 4. https://blogs.bmj.com/bmj/2014/04/04/vidhya-alakeson-what-willpersonal-health-budgets-offer-the-nhs/.

13 NHS England. Personal health budgets and integrated personal commissioning: national expansion plan. Jun 2017. https://www.england.nhs.uk/wp-content/uploads/2017/06/516 National-expansion-plan_S10.pdf.

14 Jones K, Forder J, Welch E, Caiels J, Fox D. Personal health budgets: process and context following the national pilot programme. Working paper 2947. Personal Social Services Research Unit. 19 Jun 2017. https://www.pssru.ac.uk/pub/5331.pdf.
15 Jones K, Caiels J, Forder J, Windle K. Evaluation of the personal health budgets pilots: outline of a research project funded by the Department of Health (P91). Jan 2010. https: //www.pssru.ac.uk/pub/p091.pdf.

16 National Audit Office. Personalised commissioning in adult social care. HC 883 session 2015-16. 3 Mar 2016. https://www.nao.org.uk/wp-content/uploads/2016/03/Personalisedcommissioning-in-adult-social-care-update.pdf.

17 Duffy S. In defence of personal health budgets. Open Democracy 2016 Apr 1. https:// www.opendemocracy.net/en/ournhs/in-defence-of-personal-health-budgets/.

18 Beresford P, Slasberg C. NHS personal budgets-a failing strategy driven by neo-liberal ideology. Centre for Labour and Social Studies. 25 Apr 2018. http://classonline.org.uk/ blog/item/nhs-personal-budgets-a-failing-strategy-driven-by-neo-liberal-ideology.

19 Duffy S. Will personal health budgets destroy the NHS? Socialist Health Association. 2 Sep 2015. https://www.sochealth.co.uk/2015/09/02/will-personal-health-budgets-destroythe-nhs/.

20 Health and Social Care Committee. Written evidence from National Pensioners Convention (SC 22). Oct 2011. https://publications.parliament.uk/pa/cm201012/cmselect/cmhealth/ 1583/1583vw17.htm.

21 NHS personal health budgets spent on holidays and horse riding. BBC News 2015 Sep 1. https://www.bbc.co.uk/news/health-34110964.

Published by the BMJ Publishing Group Limited. For permission to use (where not already granted under a licence) please go to http://group.bmj.com/group/rights-licensing/ permissions 